\title{
ETHNOGRAPHIES \\ OF \\ ISLAM IN CHINA
}





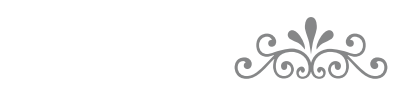

ETHNOGRAPHIES

$\mathrm{OF}$

ISLAM IN CHINA

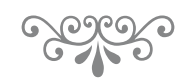

\section{Edited by Rachel Harris, \\ Guangtian Ha, and Maria Jaschok}

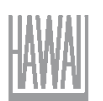

University of Hawai'i Press

Honolulu 


\author{
(C) 2021 University of Hawai'i Press \\ All rights reserved \\ Printed in the United States of America \\ $262524232221 \quad 6554321$
}

\title{
Library of Congress Cataloging-in-Publication Data
}

Names: Harris, Rachel (Rachel A.), editor. I Ha, Guangtian, editor. I Jaschok, Maria, editor.

Title: Ethnographies of Islam in China / edited by Rachel Harris, Guangtian Ha, Maria Jaschok.

Description: Honolulu : University of Hawai'i Press, [2021] I Includes bibliographical references and index.

Identifiers: LCCN 2020012154 (print) I LCCN 2020012155 (ebook) I ISBN

9780824883348 (hardcover) I ISBN 9780824886431 (pdf) I ISBN

9780824886448 (epub) I ISBN 9780824886455 (kindle edition)

Subjects: LCSH: Muslims—China. I Islam-China. I Uighur (Turkic people)—China_Religion. I Hui (Chinese people)—China-Religion. I Islam and state-China.

Classification: LCC DS731.M87 E84 2021 (print) I LCC DS731.M87 (ebook) I DDC 305.6/970951—dc23

LC record available at https://lccn.loc.gov/2020012154

LC ebook record available at https://lccn.loc.gov/2020012155

University of Hawai'i Press books are printed on acid-free paper and meet the guidelines for permanence and durability of the Council on Library Resources.

Cover photo: Worshippers at the shrine of Imam Aptah near Khotan. Courtesy of Rahile Dawut. 